\title{
Improper Management of Pharmaceutical Waste in South and South-East Asian Regions
}

Keywords: Drug disposal; Household; Drug take-back; Hospital waste; Pharmacists; Landfill disposal

\begin{abstract}
Medical wastes entered our ecosystem owing to improper disposal practice which exploited as pollutants and posed huge threat to the public health, economy and eco-system. This review had scrutinized and illustrated the erroneous drug disposal practice, their possible threats, and proposed several probable solutions for proper pharmaceutical waste management. Findings of this study claimed immediate attention of the government especially of the developing countries like South and South-East Asian (SSEA) to develop policies in order to abolish all the implementation obstacles. The literature studied includes $66 \%$ of pharmaceuticals waste generated from households, $13 \%$ from community pharmacy and $20 \%$ from hospital pharmacy from year 2009 to 2015 in SSEA regions. In most of the cases, liquid pharmaceuticals were disposed via toilet/sink and solid dosage forms were discarded via trash/bin. Acknowledgment of proper drug disposal and hazardous consequences of improper disposal varied among each category of the participants. Although awareness among healthcare professionals was higher, still no useful actions had been taken. Besides the drug take-back program, other alternative economical ways are highlighted to reduce the generation of unused/expired medicines. Advancements of technical innovations and involvement of environmental scientists, physicians, pharmacists and media are also indispensible to raise awareness.
\end{abstract}

\section{Introduction}

With increase the number of hospitals and pharmaceuticals, the amount of medical waste is increasing and awareness about drug disposal needs to be enhanced [1]. Several dimensions of environmental risk have been created by the improper disposal of drugs. Such as a very minor level of ethinyl estradiol in water can cause impaired sexual development and feminization of fishes [2]. Still, implementation of proper drug disposal remains dismal because many countries still do not have standard medication disposal protocols. Recent studies that were conducted in USA \& UK proved that the treatment plants that were used for removing pharmaceutical compounds were not sufficiently effective [3].

On the contrary, Sweden has a well-established reversed distributional system which helps to dispose the drugs properly [4]. Unlike Sweden, there are many SSEA countries that don't dispose unused drugs properly. Karachi, the largest city of the Pakistan produces 9000 tons of solid wastes daily, including pharmaceutical wastes which pass through drains. Among these wastes, only $20 \%$ wastes are treated for safe disposal [5]. Again Nepal and Bangladesh doesn't have any official guidelines for the proper disposal of drugs and in most cases, drugs are disposed in water and garbage [6]. Almost all SSEA countries common practice is to throw medicines in dustbin or some of these are being flushed in toilets. Most of the SSEA countries are developing and highly populated, so a small amounts of medical wastes can cause a serious public health hazards. These

\section{Environmental Studies}

\section{Nilufer Yeasmin Nipa, Shamim Ahmed, Md. Shahariar, Mashiqur Rahman, Bushra Haider and Mohammad Borhan Uddin*}

Department of Pharmaceutical Sciences, North South University, Dhaka-1229, Bangladesh

\section{${ }^{*}$ Address for Correspondence}

Mohammad Borhan Uddin, Department of Pharmaceutical Sciences, North South University, Dhaka-1229, Bangladesh, Tel: 01841777678; E-mail: bnn.nsu@gmail.com

Submission: 03 February, 2017

Accepted: 14 March, 2017

Published: 20 March, 2017

Copyright: ( 2017 Nipa NY. This is an open access article distributed under the Creative Commons Attribution License, which permits unrestricted use, distribution, and reproduction in any medium, provided the original work is properly cited.

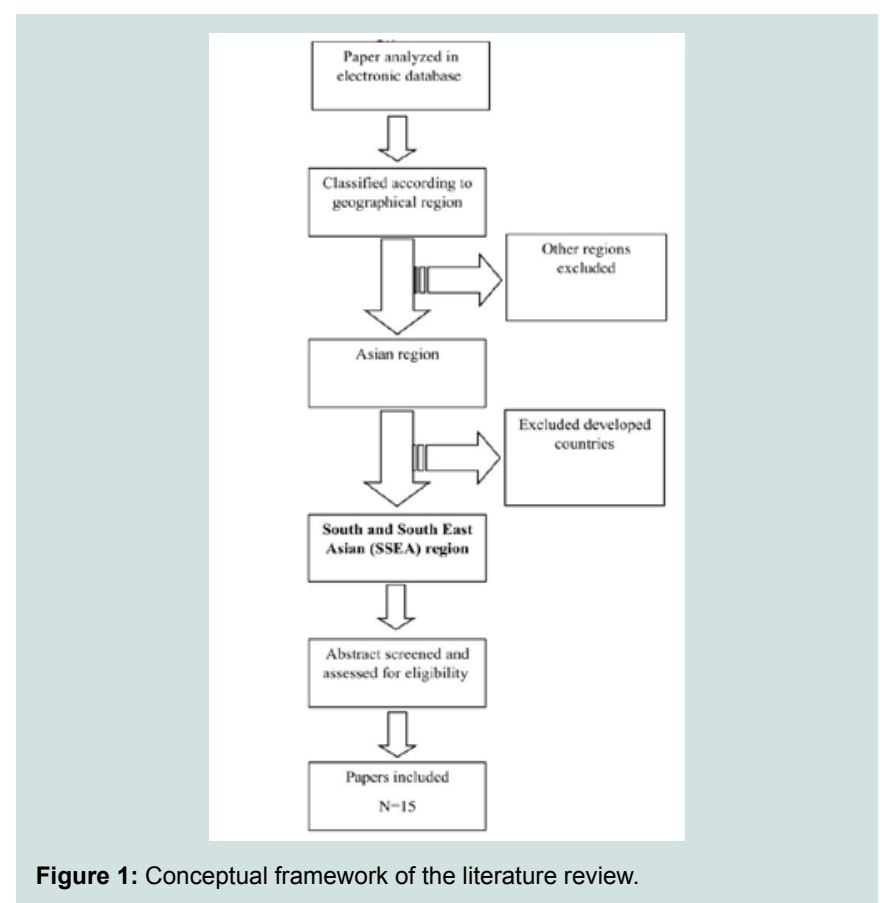

inappropriate practices result serious global issues like 'Antibiotic resistance', feminism and sexual impairment, ecological disasters etc. Unfortunately, strict and organized policies are yet to be taken.

Very urgent considerations are necessary to address this grave problem, especially in South-Asian region. This practice will help to improve the quality of the life of their people and globally it will help to reduce the de-sensitization of drugs e.g., antibiotics. However, pharmacists can play a big role in this matter. These harmful effects of disposed medicines can be reduced if the drugs collected in pharmacies are disposed by community pharmacists in a proper way $[7,8]$. 
Citation: Nipa NY, Ahmed S, Shahariar MD, Rahman M, Haider B, et al. Improper Management of Pharmaceutical Waste in South and South-East Asian Regions. J Environ Stud. 2017;3(1): 7.

ISSN: $2471-4879$

Table 1: Different studies and their methodologies found in the peer-reviewed literature.

\begin{tabular}{|c|c|c|c|c|c|c|}
\hline Region & Research instrument & $\begin{array}{l}\text { Number of } \\
\text { participants }\end{array}$ & Category & $\begin{array}{c}\text { Sources of } \\
\text { disposal }\end{array}$ & Observation & References \\
\hline Malaysia & Interview & 28 & Patients & Household & $\begin{array}{l}\text { Most frequent }(57.1 \%) \text { disposal } \\
\text { method was throwing unused } \\
\text { medication into trash; } 55 \% \text { of the } \\
\text { participants were not aware on the bad } \\
\text { effect of unused medication. }\end{array}$ & $\begin{array}{l}\text { (Al-Naggar \& Alareefi, 2010) } \\
\text { [36] }\end{array}$ \\
\hline Malaysia & Structured questionnaires & 885 & Students & Household & $\begin{array}{l}87 \% \text { of the participants knew about } \\
\text { drug waste but only } 2 \% \text { of them } \\
\text { follow drug take back system; } 83 \% \\
\text { of the participants dispose unwanted } \\
\text { medicines into landfill. }\end{array}$ & (Azad et al. 2012)[15] \\
\hline $\begin{array}{l}\text { Pakistan } \\
\text { (Karachi) }\end{array}$ & Questionnaires & 1022 & Students & Household & $\begin{array}{l}\text { Predominant method of expired } \\
\text { medications disposal is through dustbin } \\
(82.8 \%) ; 82.1 \% \text { of the respondents do } \\
\text { not have any knowledge what should } \\
\text { be done with the unused medications } \\
\text { so until it is expired they store them. }\end{array}$ & (Ahmed et al. 2013) [12] \\
\hline India & Interview & 56 & Patients & Household & $\begin{array}{l}\text { Unused medications were thrown } \\
\text { in the trash }(57.1 \%) ; 55 \% \text { of the } \\
\text { participants admitted to having no } \\
\text { knowledge about the harmful effect of } \\
\text { unused medication. }\end{array}$ & $($ Dharmender et al. 2013) [16] \\
\hline North India & $\begin{array}{l}\text { Questionnaires (both } \\
\text { open and close-ended } \\
\text { questions) }\end{array}$ & 236 & Dental students & Household & $\begin{array}{l}46 \% \text { participants acknowledged } \\
\text { that they were not aware of drug- } \\
\text { environment interaction; major mode } \\
\text { of drug (unused or expired) disposal is } \\
\text { trashing }(94 \%) \text {. }\end{array}$ & (Aditya, 2013) [19] \\
\hline $\begin{array}{c}\text { Thailand } \\
\text { (KhonKaen } \\
\text { city) }\end{array}$ & Structured interview & 331 & Villagers & Household & $\begin{array}{l}\text { Majority of the participants }(73 \%) \text { had } \\
\text { supported that drug take back program } \\
\text { could be used to manage the leftover } \\
\text { drugs issues. However, most of them } \\
(89 \%) \text { mentioned that they were not } \\
\text { being taught about safe drug disposal. }\end{array}$ & (Arkaravichien et al. 2014) [11] \\
\hline $\begin{array}{c}\text { Western } \\
\text { Nepal } \\
\text { (Pokhara city) }\end{array}$ & $\begin{array}{c}\text { Semi-structured } \\
\text { questionnaires; Interview; } \\
\text { Observation checklist }\end{array}$ & 54 & $\begin{array}{l}\text { Pharmacy } \\
\text { supervisors }\end{array}$ & $\begin{array}{l}\text { Community } \\
\text { pharmacy }\end{array}$ & $\begin{array}{l}52.36 \% \text { of the participants dispose } \\
\text { their medication waste in the municipal } \\
\text { dump; they were lack of awareness } \\
\text { about the impact of disposing } \\
\text { medicinal waste. }\end{array}$ & (Gyawali et al. 2014) [9] \\
\hline South India & $\begin{array}{l}\text { Direct interview; } \\
\text { questionnaires }\end{array}$ & 158 & Patients & Household & $\begin{array}{l}\text { Majority }(65 \%) \text { of them were not } \\
\text { aware of risk and dispose medicines } \\
\text { by throwing into the dustbin/trash } \\
(63.5 \%) \text {. }\end{array}$ & $\begin{array}{l}\text { (Radhakrishna et al. 2013) } \\
\text { [17] }\end{array}$ \\
\hline North India & $\begin{array}{c}\text { Structured questionnaires } \\
\text { containing both open and } \\
\text { close-ended questions }\end{array}$ & 84 & Pharmacists & $\begin{array}{l}\text { Community } \\
\text { pharmacy }\end{array}$ & $\begin{array}{l}\text { Around } 90 \% \text { of participant had some } \\
\text { kind of medications stored at home. } \\
\text { Whatever the dosage form, the } \\
\text { common method was disposing via } \\
\text { dustbin. }\end{array}$ & (Aditya \& Rattan, 2014) [34] \\
\hline South India & $\begin{array}{l}\text { Face to face semi- } \\
\text { structured interview }\end{array}$ & 127 & Pharmacists & Household & $\begin{array}{l}63.9 \% \text { of the participant were not } \\
\text { aware of environmental hazards; } \\
\text { disposal of unwanted medicines by } \\
\text { throwing in trash }(35 \%) \text {. }\end{array}$ & $\begin{array}{l}\text { (Radhakrishna \& Nagarajan, } \\
\text { 2015) [10] }\end{array}$ \\
\hline $\begin{array}{l}\text { Malaysia } \\
\text { (Rawang) }\end{array}$ & $\begin{array}{l}\text { Questionnaires (close } \\
\text { ended questions) }\end{array}$ & 384 & $\begin{array}{l}\text { Parents of } \\
\text { school aged } \\
\text { children }\end{array}$ & Household & $\begin{array}{l}69.5 \% \text { of the respondents were not } \\
\text { aware of medication wastes; Majority } \\
\text { of them }(74.3 \%) \text { turf out medication } \\
\text { waste into trash bin. }\end{array}$ & (Avalee \& Hassan, 2015) [35] \\
\hline
\end{tabular}

This study is the first attempt to focus on the improper disposal of drugs in SSEA regions and on the possible threats to the environment which violate human health. The study also pays attention to find a way to dispose the drugs in the simplest way and to build a proper management system for suitable disposal of drugs. It also has an objective to make people aware about the biological destructive effects of drugs that occur due to improper disposal of drugs. 
Citation: Nipa NY, Ahmed S, Shahariar MD, Rahman M, Haider B, et al. Improper Management of Pharmaceutical Waste in South and South-East Asian Regions. J Environ Stud. 2017;3(1): 7.

ISSN: $2471-4879$

Table 2: Methods of disposal of leftover/expired medication.

\begin{tabular}{|c|c|c|c|c|c|c|}
\hline \multirow[b]{2}{*}{ Region } & \multirow[b]{2}{*}{ Sample size } & \multicolumn{4}{|c|}{ Method of disposal } & \multirow[b]{2}{*}{ References } \\
\hline & & $\begin{array}{c}\text { Dustbin or } \\
\text { trash }\end{array}$ & $\begin{array}{l}\text { Sink or } \\
\text { toilet }\end{array}$ & Other(s) & $\begin{array}{l}\text { Return to } \\
\text { pharmacy }\end{array}$ & \\
\hline Pakistan (Karachi) & 1022 & $80 \%$ & $11.5 \%$ & - & $2 \%$ & (Ahmed et al. 2013) [12] \\
\hline India & 56 & $57.1 \%$ & $3.6 \%$ & $14.2 \%$ (burning) & $5.3 \%$ & (Dharmender et al. 2013) [16] \\
\hline North India & 236 & $94 \%$ & $32 \%$ & - & $3 \%$ & (Aditya, 2013) [19] \\
\hline $\begin{array}{l}\text { Western Nepal } \\
\text { (Pokhara city) }\end{array}$ & 54 & $52.36 \%$ & - & - & - & (Gyawali et al. 2014) [9] \\
\hline South India & 480 & $45.97 \%$ & $25.03 \%$ & $\begin{array}{c}3.75 \% \text { (sanitary } \\
\text { landfill) }\end{array}$ & $16.97 \%$ & (Nagarajan et al. 2014) [21] \\
\hline South India & 127 & $35 \%$ & $15.5 \%$ & $\begin{array}{c}6.8 \% \text { (landfill, } \\
\text { burning) }\end{array}$ & $30.7 \%$ & (Radhakrishna \& Nagarajan) [10] \\
\hline
\end{tabular}

\section{Material and Methods}

In the primary peer-review literatures, the total number of 15 research studies in SSEA region was identified. Figure 1 outlined the primary steps of the paper selection. Initially, Phrases like "used and expired drug disposal" "household drug disposal" and their numerous synonyms were used in the search engine. Only the clearly inscribed original journals of the developing countries of SSEA were included. At first, the articles were recruited on the basis of titles then two individual separately scrutinized throughout the abstract, methodologies and the results for final inclusion.

The summary of these studies is presented in the Tables 1-4 to get the possible ideas about the practices of unused and expired medication in the SSEA region. The studies were done between years 2009-2015 (except one). Among 15 papers, 6 of them are from India,

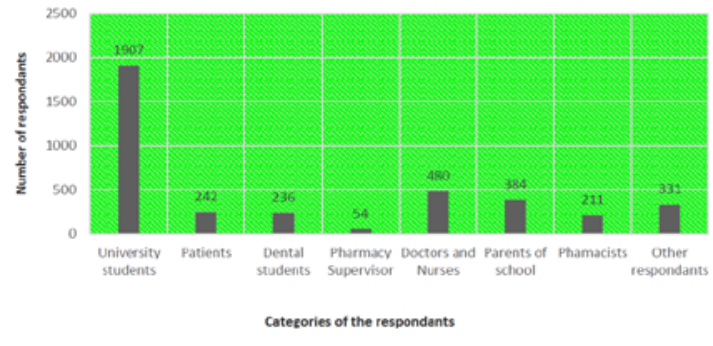

Figure 2: The responses from different categories of participants in interview and questionnaire.
3 from Bangladesh, 3 from Malaysia, 1 from Thailand, 1 from Nepal and 1 from Pakistan. Papers of Bhutan, Maldives and other SSEA regions, haven't been found.

The range of methods used to deliver the questionnaire to participants included Structured questionnaires, Structured interview, Semi-structured questionnaires, Open and close-ended questions, Face to face semi-structured interview. Three studies employed both interview and questionnaires. Location, number of participants, age, and educational status of participants and category of participants are varied among the studies. The total number of participants in all the studies was 3845 , the categories of participants are presented in the Figure 2.

\section{Sources of drug disposal}

All studies enclosed here can be categorized based on sources of disposal as: a) 10 were from households; b) 2 were from community pharmacy; and c) rest were from hospital waste management.

\section{Results and Discussion}

Table 1 summarizes the drug disposal habits and socioenvironmental impacts of different regions of SSEA countries. Extent of awareness about medicament waste among participants seemed to increase, but in case of proper application of the disposal method still no significant improvement had been noticed from year 2009 to 2015. The synopsis of the finidings apprised that pharmacists were more aware about the consequences of medicinal waste, yet no implications were made $[9,10]$. Widespread method of drug disposal in all the studies was to discard the medicines into trash/dustbin which will eventually end up in municiple dump.

\section{Prevalence and rationale of leftover drugs}


Citation: Nipa NY, Ahmed S, Shahariar MD, Rahman M, Haider B, et al. Improper Management of Pharmaceutical Waste in South and South-East Asian Regions. J Environ Stud. 2017;3(1): 7.

ISSN: $2471-4879$

Table 3: Respondent's practice of drug disposal based on different dosage forms.

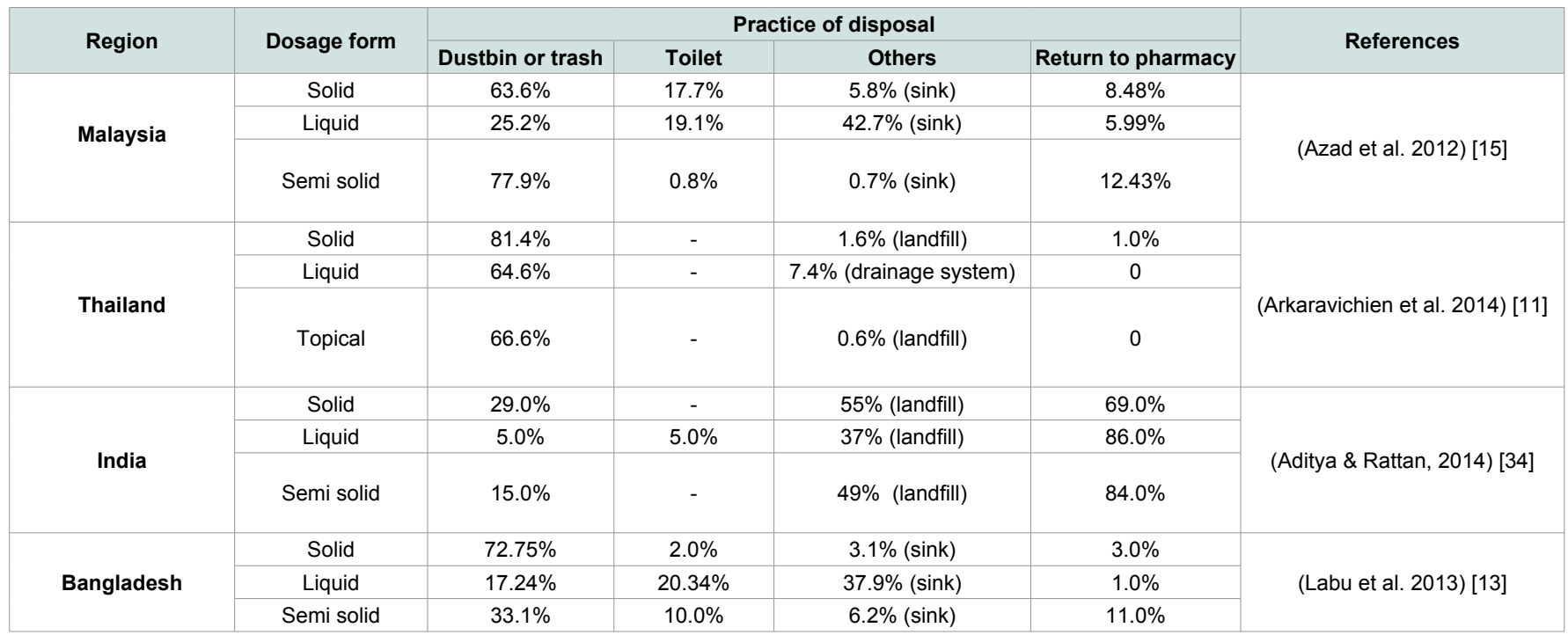

Table 4: Thoughts of the participants for creating awareness on safe drug disposal practice.

\begin{tabular}{|c|c|c|c|c|}
\hline \multirow[b]{2}{*}{ Region } & \multicolumn{3}{|c|}{ Manners to create awareness (\%) } & \multirow[b]{2}{*}{ References } \\
\hline & $\begin{array}{l}\text { Electronic } \\
\text { Media }\end{array}$ & $\begin{array}{c}\text { Physician and } \\
\text { pharmacist }\end{array}$ & Other (stated) & \\
\hline Malaysia & 40.1 & 24.7 & 35.2 (Newspaper) & (Avalee \& Hassan, 2015) [35] \\
\hline India & 18 & 75 & 7 (Newspaper) & (Nagarajan et al. 2014) [21] \\
\hline Bangladesh & 3.2 & 35.48 & 32. 25 (Newspaper) & (Labu et al. 2013) [13] \\
\hline India & 3.6 & 10.8 & 67.7 (Education) & (Dharmender et al. 2013) [16] \\
\hline Pakistan & 51 & - & 20 (Newspaper) & (Ahmed et al. 2013) [12] \\
\hline
\end{tabular}

In a survey of Thailand, around $90 \%$ of the respondents had agreed to have leftover medicines at home [11]. Similarly, in Pakistan, almost $80 \%$ answered "yes" for medicines left at home. Many participants suggested patient compliance and proper guidance might reduce number of leftover or expired medicines [12].

From literature, it was found that most of the people in Pakistan $(82.8 \%)$ and in Bangladesh (55.5\%) stored the unused medicines at home until it expired $[11,13]$ because most of them acknowledged that they did not know what to do with the unused medicine. Another major reason for storing expired drug was more than half of the population participants didn't know how to dispose the medication properly [14-17]. Moreover, in a survey of south Indian patients, $9 \%$ respondents also mentioned they had witnessed few accidental drug poisoning in children or adults [17]. Similarly, about 23783 drug intake cases were reported to USA Poison Control centers due to unintentional medicine intake. Among them around $21 \%$ of the victims were children of 6 years or less [18].

A household study conducted in North India, showed that $72 \%$ of the participants had at least 1 to 5 medicines or around 19\% people had 6 to10 unused medicines stored at home. This study illustrates that the surplus OTC (Over the counter) drug purchase (53\%) and self-discontinuation (17\%) is also the other popular reasons for the leftover medicines [19]. In another survey in Bangladesh, it had been found that approximately half $(51.72 \%)$ of the participants agreed that they had bought medicines without prescriptions which led to leftover medicines later on [13]. Problem that arouse due to excess leftover drugs could be minimized by enrolling pharmacists whose obligation would be to counsel patients about completing drug regime, monitoring excess OTC drug purchase, advising about proper disposal of drug, and to counsel the patients to return unused medicines in the pharmacy. 
Non-steroidal Anti-inflammatory Drugs (NSAIDs) (30\%) and antibiotics (21\%) were the common class of drugs which were leftover until it is expired in Pakistan. A similar result was found in India where the frequency of NSAIDs were $38 \%$ and antibiotics were $36 \%$ $[12,17]$. In fact, a study in Nigeria gives similar results about common leftover medicines like analgesics (36.4\%) and antibiotics (33.1\%) [20].

\section{Conventional drug disposal methods}

From the study of several literatures, it has been observed that in Pakistan, India, Thailand, Malaysia, Nepal and Bangladesh, the most usual method of disposing medicament was via trash/dustbin. The second most popular disposal route was flushing down through sink/ toilet. Very few participants return the expired or leftover medicines to the pharmacy for proper disposal $[11,16,17,19]$. Detailed percentages of disposal methods are illustrated in Table 2.

On the contrary, in India, doctors and nurses demonstrated that 46.3\% participants returned their medicines to the pharmacy, but at the same time around $50 \%$ of the subjects still dumped medicines in the dustbin; being unaware (83.3\%) of the environmental hazards [21].

\section{Influence of dosage form on the drug disposal practice}

Bangladesh complies that liquid dosage forms are often flushed in toilet $(37.9 \%)$ or sink $(20.34 \%)$ in the domestic water system whereas the solid (72.5\%) and the semi-solid (33.1\%) dosage forms are dumped in the trash with other household garbage [13]. Table 3 outlined the influence of dosage form on the drug disposal methods in different countries.

Furthermore, in Malaysia, $62 \%$ of the participants disposed liquid dosage forms via sink or toilet and $27 \%$ dumped via bin and only $6 \%$ was returned for safe disposal. However in Thailand, dumping the liquid medications in trash (64.6\%) was significantly higher than putting them in sinks or toilet drainage system (7.4\%). It was found that the method of disposing was independent of the dosage forms in few countries, so whatever the dosage form was throwing into dustbin was the most popular practice [11]

\section{Hospital waste and drug disposal}

Hospital does not deal with unused medicines, but still it contains infectious biomedical waste of about $15 \%$ to $20 \%$ of the total hospital wastes [22]. Hospital and pharmacy waste pose a great threat to the environment and humans. Few findings from Bangladesh and Nepal mentioned that knowledge about proper medical waste disposal was very low. Even $38 \%$ of the cleaners, nurses, laboratory technicians said that they weren't given any training regarding the handling of medical wastes. Around $60 \%$ of the wastes were dumped into municipal bins without any treatment or separation [14]. Additionally, selling medical wastes like disposable syringes were also witnessed in these studies $[9,14,22]$. In South Asia, reusing syringes and needles was very frequent (about 75\%) and is extensively practiced in Nepal. Reusing syringes without proper sterilization possessed a grave public health concern [23]. It has been estimated that unsafe administration of injections worldwide gives rise to infections such as new cases of Hepatitis B virus (33\%), Hepatitis C virus (42\%) and Human Immunodeficiency Virus (2\%) annually [24].
Another mainstream method was burning wastes in open air even though it was not recommended by WHO due to potential risks to the staff, society and the environment $[9,14]$. Urgent initiatives need to be undertaken to reduce contamination, risks of infection and to raise awareness about medical waste issues among people.

\section{Effect of drug disposal on the environment}

Improper disposal of leftover and unwanted drugs by household and medical facilities is a source of contamination and pollution, making it a health and an environmental hazard. Many are unsure about the appropriate way of drug disposal as standard drug disposal protocols are not present in most countries. Throwing in the trash, rinsing down the sink or flushing them down the toilet is found to be the most common ways of discarding drugs. As a result of improper and unregulated disposal of drugs, water supplies and local sources are contaminated causing probable effects on the ecosystem. A number of reports show the presence of pharmaceuticals in ground water, lakes, rivers and drinking water [8].

Veterinarian practices, human excretion of drugs, pharmaceutical industries and improper disposal of unused or expired pharmaceuticals are the few ways by which pharmaceutical products enter the water supply [25]. Some recent studies done in US and UK mentioned that the pharmaceuticals were not removed by the water treatment systems available [3]. According to Jones et al. (2007) and Fent et al. (2006), conventional sewage treatment plants are inefficient in removing pharmaceutical compounds as they are primarily designed to remove and treat human excrements and not anthropogenic substances [26,27].

Amount of pharmaceuticals found in water was in minuscule concentration, commonly in parts per billion (ppb) and parts per trillion. Even at such low levels it affects aquatic animals [28]. Environmental effects like development of female traits in male fish leading to reproduction, sex, genital deformities and even population collapse is the result of bioaccumulation of these pharmaceuticals $[8,29]$. In an article, it was indicated that feminism and sexual development impairment was a result of the presence of trace amount of ethinyl estradiol, an oral contraceptive component. Additionally, harmful chemicals entered into the food chain through drinking water. About $80 \%$ fruits and vegetables in Pakistan are irrigated using waste water and in another study multi-resistant Salmonella was found in the water used on vegetables in India [12].

Cattle had been found to die in Asian countries after intake of pharmaceuticals that were thrown in the local dumping grounds. Also, endangered vultures in Asia have been dying from preying on cattle's and their carcasses containing relatively low levels of diclofenac [30]. Indian subcontinent faced a large scale ecological disaster for improper drug disposal and one of the main causes of such incidence is leftover household medicines being inappropriately disposed [31].

Leftover drugs and improper drug disposal also leads to antibiotic resistance which is a major concern [17]. Among the common classes of leftover and unused drugs found in household surveys antibiotics was found to be one of the highest (21\% in Pakistan, 36\% in India and $31.5 \%$ in Malaysia) which makes it easier to enter the environment. Trace amount of antibiotics in the effluent may facilitate the transfer 


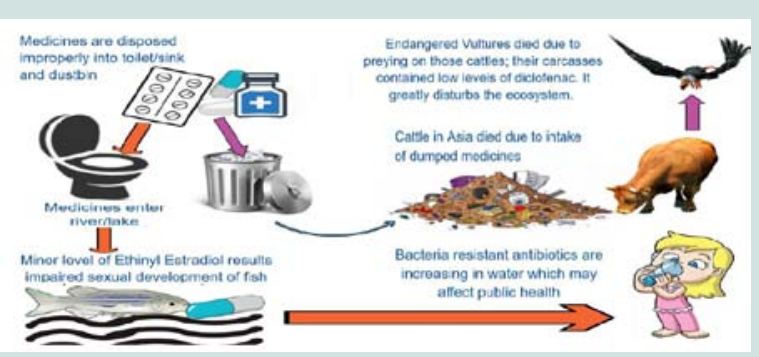

Figure 3: Environmental consequences due to improper drug disposal.

of resistant genes from non-resistance microbes to deadly resistance microbes by increasing the selection pressure. This in turn increases the emergence of deadly resistant microorganisms [32]. Several studies have shown a decline in the effectiveness of antibiotics and make it an alarming threat in treating life threatening infections. For example, in India bacteria resistant to ciprofloxacin was found in pharmaceutical plants [33].

In Bangladesh, hospital waste management that documented safe disposal of medical waste had been ignored. Wastes from various departments were discarded into municipal bins which were then carried to landfill areas for final disposal. When these wastes end up in open areas, scavengers sort them out in the hope of selling which can be recycled. As a result, they became vulnerable to infections and serious injuries as they do that without taking any precautions. Along with other environmental hazards, these wastes attract scavenging animals, give off foul smell, promote fly feeding and pollute both water and air as it ferments. Pathogens are reintroduced into the human body through the food chain when domestic animals graze in such areas [22].

\section{Degree of awareness of safe drug disposal}

Consciousness level for the safe disposal of drug was very poor among the SSEA countries. A bottle neck work had been done on this issue; however, these countries should be more emphasized than other developed countries due to its high drug abuse, unhygienic sanitation, poor living state, etc. Studies (Table 4) on the available literatures had clearly reflected the inadequate awareness about safe drug disposal even among the health care professionals as well as the literates. Survey reports from India mentioned that more than $80 \%$ of the medical doctors and nurses [21], 65\% patients [17], and 58\% pharmacists [34] were unaware about safe drug disposal. In order to create awareness, the majority of the participants wanted advice from pharmacists and physicians in India (75\%) [17], in Bangladesh (35.48\%) [13] and in Malaysia (24.7\%) [35]. In addition to this, educating in school, college, university through campaign was also a popular choice in India (67.7\%) [16] and Malaysia (60.7\%) [36]. Moreover, the media were the common choice in Pakistan (51\%) [11]) and Malaysia (40.1\%) [35]. In few studies, respondents also said that drug companies, social media should step forward to enlighten the society about safer drug disposal practice [16,21].

\section{Plausible preventive measures}

Day by day, enormous rise in pharmaceuticals in our water results from unsafe disposal of drug either by flushing down the toilet or by throwing in the trash. The perfect method was giving expired drug back to the authority to dispose appropriately via community drug 'take back' programs, yet it is not available in most of SSEA countries therefore leaving people with very less choices. Previously a study was carried on community pharmacists where many subjects (73\%) stated that 'drug take back program' could reduce this problem of improper medical disposal [34]. In another study, it was found that almost half of the pharmacists (47.3\%) refused to use pharmacy as a drug take back center; however, at the same time they have chosen pharmacy as one of the best options to return the drug. The reason behind this dilemma of 'drug take back system' could be the absence of guidelines about proper disposal procedures among the pharmacists (81\%) [10]. Also, $72 \%$ of the pharmacists of an Indian survey suggested returning unused drugs to the government hospital as the best option [34]. Instead of throwing many expensive medicines into trash or making them expired, unused medicines could be donated to those who cannot afford them. Certain developed countries, like USA, has well maintained drug 'take-back' systems which play a significant role in distributing and disposing medicines correctly [37]. More environmental practices like incineration and disposing in impermeable containers with refuse solids like coffee grounds [38] must be implemented for the unused and inappropriately disposed pharmaceuticals analgesics, antibiotics and agents that act on the central nervous system like controlled drugs such as opioids are present which have addictive potential.

\section{Conclusion}

- Findings of this study reflected the present scenario regarding the methods of medicament waste disposal in houses, pharmacies and hospitals from different areas of SSEA countries. These collated studies emphasized the urgency for proper disposal methods. Conclusions of the investigated literatures are depicted (Figure 3) and outlined below. Extremely poor knowledge and awareness about improper medicament waste disposal, and its hazardous consequences among SSEA people and environment was reported.

- Respondents mainly voted for organizing seminars by environmental scientists, physicians and pharmacists might help to raise awareness to mass community. Moreover, doctors, nurses and hospital and community pharmacists can also be enlightened through campaigns, workshops. Along with these, awareness through electronic media and newspaper appeared to be more preferable.

- Apparently, immediate extensive researches are mandatory because the most popular disposal method had the ability to cause disastrous environmental effects.

- Management of pharmaceutical waste required to set up programs like drug take-back system to recycle unused drugs, which can be donated to the poor patient in the rural government hospital. Further analysis is essential for the development of official guidelines which would be relevant and specific for each country. Collecting the expired drugs by state run-collection programs might clear the confusions about the 'proper' manner to dispose medications. Training the technicians and cleaners of hospitals about proper handling of medical waste disposal might reduce the risk too. 
Citation: Nipa NY, Ahmed S, Shahariar MD, Rahman M, Haider B, et al. Improper Management of Pharmaceutical Waste in South and South-East Asian Regions. J Environ Stud. 2017;3(1): 7.

ISSN: $2471-4879$

However, the limitation is that few SSEA countries like Maldives, Bhutan and others didn't have any related studies. Still, more researches should be carried on to draw a better-informed actual scenario of this grave matter.

\section{References}

1. Halling-Sorensen B, Nors Nielsen S, Lanzky PF, Ingerslev F, Holten Lutzhoft $\mathrm{HC}$, et al. (1998) Occurrence, fate and effects of pharmaceutical substances in the environment--a review. Chemosphere 36: 357-393.

2. Jobling S, Williams R, Johnson A, Taylor A, Gross-Sorokin M, et al (2006) Predicted exposures to steroid estrogens in U.K. rivers correlate with widespread sexual disruption in wild fish populations. Environ Health Perspect 114 Suppl 1: 32-39.

3. Stackelberg PE, Furlong ET, Meyer MT, Zaugg SD, Henderson AK, et al. (2004) Persistence of pharmaceutical compounds and other organic wastewater contaminants in a conventional drinking-water-treatment plant. Sci Total Environ 329: 99-113.

4. Gotz K, Keil F (2007) Drug disposal in private households: Does the disposa of pharmaceuticals via domestic sanitary devices contribute to water contamination? Umweltwissenschaften und Schadstoff-Forschung 19: 180 188

5. Ahmed R, Ahmed N (2008) Case study report: Healthcare waste management in karachi, Pakistan. Advisers on Urban Environment and Development, The Netherlands.

6. (2011) Solid waste management act.

7. Costanzo SD, Murby J, Bates J (2005) Ecosystem response to antibiotics entering the aquatic environment. Mar Pollut Bull 51: 218-223.

8. Glassmeyer ST, Hinchey EK, Boehme SE, Daughton CG, Ruhoy IS, et al. (2009) Disposal practices for unwanted residential medications in the United States. Environ Int 35: 566-572.

9. Gyawali S, Rathore DS, Adhikari K, Shankar PR, K C VK, et al. (2014) Pharmacy practice and injection use in community pharmacies in Pokhara city, Western Nepal. BMC Health Serv Res 14: 1-12.

10. Radhakrishna L, Nagarajan P (2015) Pharmacists opinion and practice towards disposal of unused medication in South India. World J Pharm Sci 3: 654-657.

11. Arkaravichien W, Ruchipiyarak T, Thawinwan W, Benjawilaikul S (2014) A threat to the environment from practice of drug disposal in Thailand. Environ Asia 7: 13-18.

12. Ahmed A, Mushtaq N, Tariq M, Durrani M, Akhtar S, et al. (2013) Disposa practices of unused and expired pharmaceuticals in Karachi and their impact on health and environment. J University Med Dental Coll 4: 42-48.

13. Labu ZK, Al-Mamun MA, Harun-or-Rashid M, Sikder K (2013) Knowledge, awareness and disposal practice for unused medications among the students of the private University of Bangladesh. J Biomed Pharm Res 2: 26-33.

14. Akter N, AMR C, Kazi NM (1998) Hospital waste disposal in Bangladesh with special reference to Dhaka City and its environmental evaluation. Int Cen Diarrhoeal Dis Res Bangladesh 87: 1-36.

15. Azad AK, Ansary RH, Akhter A, Al-Mamun SM, Uddin M, et al. (2012) Disposa practice for unused medications among the students of the International Islamic University Malaysia. J Appl Pharm Sci 2: 101-106.

16. Dharmender G, Ashutosh G, Ansari NA, Ahmed QS (2013) Patient's opinion and practice toward unused medication disposal: a qualitative study. J Pharm Sci Innovation 2: 47-50.

17. Radhakrishna L, Nagarajan P, Vijayanandhan SS (2013) Practice towards disposal of medicines (Left Out/Expired Drugs) among the patients visiting tertiary care teaching hospital and Primary Health Centre in South India Asian J Biochem Pharm Res 4: 175-182.
18. Bronstein AC, Spyker DA, Cantilena LR Jr, Green JL, Rumack BH, et al (2008) 2007 Annual Report of the American Association of Poison Control Centers' National Poison Data System (NPDS): 25th Annual Report. Clin Toxicol (Phila) 46: 927-1057.

19. Aditya S (2013) Safe medication disposal: need to sensitize undergraduate students. Int J Pharm Life Sci 4: 2475-2480.

20. Auta A, Banwat S, Sariem C, Shalkur D, Nasara B, et al. (2012) Medicines in pharmacy students' Residence and Self-medication Practices. J. Young Pharm 4: 119-123.

21. Radhakrishna L, Nagarajan P, Vijayanandhan SS, Ponniah T (2014) Knowledge, attitude and practice (KAP) towards disposal of medicines: a qualitative study among health care professionals in South India. World J Pharm Res 3: 1955-1963.

22. Zerin SA, Ahmed MB (2009) Hospital waste management in Dhaka: a threat Bangladesh Res Publ J 3: 796-811.

23. Hutin YJ, Hauri AM, Armstrong GL (2003) Use of injections in healthcare settings worldwide, 2000: literature review and regional estimates. BMJ 327 : 1075.

24. WHO (2011) Injection safety: Safe injection Global Network-Advocacy booklet. World Health Organization, pp.25.

25. Ruhoy IS, Daughton CG (2008) Beyond the medicine cabinet: an analysis of where and why medications accumulate. Environ Int 34: 1157-1169.

26. Fent K, Weston AA, Caminada D (2006) Ecotoxicology of human pharmaceuticals. Aquat Toxicol 76: 122-159.

27. Jones OA, Green PG, Voulvoulis N, Lester JN (2007) Questioning the excessive use of advanced treatment to remove organic micropollutants from wastewater. Environ Sci Technol 41: 5085-5089.

28. Daughton CG, Ternes TA (1999) Pharmaceuticals and personal care products in the environment: agents of subtle change? Environ Health Perspect 107 Suppl 6: 907-938

29. Musson SE, Townsend T, Seaburg K, Mousa J (2007) A continuous collection system for household pharmaceutical wastes: a pilot project. J Air Waste Manage Assoc 57: 828-835

30. Oaks JL, Gilbert M, Virani MZ, Watson RT, Meteyer CU, et al. (2004) Diclofenac residues as the cause of vulture population decline in Pakistan. Nature 427: 630-633

31. Daughton CG (2010) Drugs and the environment: stewardship and sustainability. National Exposure Research Laboratory, Environmental Sciences Division, US EPA, Las Vegas, Nevada, report NERL-LV-ESD 10/081, EPA/600/R-10/106, pp.199.

32. Colborn T, vom Saal FS, Soto AM (1993) Developmental effects of endocrinedisrupting chemicals in wildlife and humans. Environ Health Perspect 101: 378-384.

33. Waghulkar VM (2010) Dark side of PPCP: an unconscious infiltration into environment. Int J ChemTech Res 2: 899-902.

34. Aditya S, Rattan A (2014) Minimizing pharmaceutical waste: the role of the pharmacist. J Young Pharm 6: 14-19.

35. Avalee M, Hassan H (2015) Disposal practice of unused medications among parents of school aged children in Rawang Selangor, Malaysia. J Pharmacol Toxicol Investigations 1: 22-26.

36. Al-Naggar RA, Alareefi A (2010) Patientsû opinion and practice toward unused medication disposal in malaysia: A qualitative study. Thai J Pharma Sci 34: 117-123.

37. Executive Summary: reducing prescription drug misuse through the use of citizen mailback program in Maine (2010) U S: Environmental Protection Agency.

38. Jarvis Cl, Seed SM, Silva M, Sullivan KM (2009) Educational campaign for proper medication disposal. J Am Pharm Assoc (2003) 49: 65-68. 